\title{
Modeling the process of hydromechanical amber extraction
}

\author{
Yevhenii Malanchuk ${ }^{1 *}$, Viktor Moshynskyi ${ }^{2}$, Valerii Korniienko ${ }^{3}$ and Zinovii Malanchuk ${ }^{3}$ \\ ${ }^{1}$ National University of Water Management and Nature Resources Use, Department of Automation, \\ Electrical Engineering and Computer-Integrated Technologies, 11 Soborna St., 33028 Rivne, Ukraine \\ ${ }^{2}$ National University of Water Management and Nature Resources Use, Department of Land \\ Management, Cadaster, Land Monitoring and Geoiformatics, 11 Soborna St., 33028 Rivne, Ukraine \\ ${ }^{3}$ National University of Water Management and Nature Resources Use, Department of Development \\ of Deposits and Mining, 11 Soborna St., 33028 Rivne, Ukraine
}

\begin{abstract}
The paper represents a process of hydromechanical amber extraction modeling to obtain input data and substantiate operation parameters of mining equipment to develop the improved hydromechanical technique of amber extraction. Intensification of amber mining process is possible when sandy deposit is saturated by water and air. Moreover, mechanical impact by means of vibration is added. Amber displacement within sandy deposit is considered. The deposit is characterized by environmental resistance when influence factors act on the process of amber surfacing. Amber concentration distribution over a deposit surface involving determination of floating periods of different amber fractions in terms of different operation modes as well as computer experiment concerning the amber grades and its distribution over amberbearing deposit involved the use of computer environment Matlab. Adequate mathematical model to solve one-dimensional boundary problems for systems of parabolic and elliptic differential equations within partial first-order derivatives on one spatial variable and time has been developed. The model describes accurately the behaviour of different amber fractions within amber-bearing deposit in terms of vibration effect as well as water and air supply.
\end{abstract}

\section{Introduction}

Ukraine is very rich in mineral resources. Three major classes of mineral resources considered to be important in our country: fuel mineral resource as well as metallic and nonmetallic. Fuels include deposits of black and brown coal, natural gas and peat. At the same time, it is one of the richest places in the world for reserves of manganese ore which is used in the manufacture of high-quality steel [1-5]. Despite conventional mineral resources mining, an amber mining is widespread in Ukraine [6, 7].

In the world, amber is deposited at the Baltic Sea in Baltic countries, Poland, Germany, Denmark, Sweden, and Belarus. Until recently, Prymorske deposit in Kaliningrad Region

\footnotetext{
*Corresponding author: e.z.malanchuk@nuwm.edu.ua
} 
(Russia) has been the largest one [8-10]. According to the proven amber reserves, Ukraine ranks third in the world after Poland (700000 tons) and Russia (160000 tons) [11 - 14].

Significant amber deposits have been prospected in the north of Volyn, Rivne, Zhytomyr, and Kyiv Regions (Ukraine). Depth of commercial Ukrainian amber deposits are 2.5 to $10.0 \mathrm{~m}$; their total thickness is $0.5-5.0 \mathrm{~m}$. Amber content within the amber-bearing deposits vary from several grams to hundreds grams per cubic meter of rock; total estimated amber Ukrainian reserves are more than 100000 tons. In the context of the deposits, average amber content is more than $50 \mathrm{~g} / \mathrm{m}^{3}[12,15]$.

Two amber deposits have been prospected in Rivne Region: Klesiv deposit in Sarny District and Vilne deposit in Dybrovytsia District; they are mined currently by the state enterprise "Burshtyn Ukrainy". In the context of Rivne region, total area of promising amber-bearing levels is 3810 square kilometers to be $18 \%$ of its territory [11, 12].

At the territories, amber is extracted mechanically and hydraulically. Residuals of the mineral with $-5.0 \mathrm{~mm}$ size is the extraction techniques disadvantage. Complete amber mining from amber-bearing deposits needs the improvement of its extraction technique with the use of new influence factors (i.e. water, air, and vibration) as well as primary gemological characteristics (refractive index, specific gravity and fluorescence $[11,16]$.

Thus, the improvement of amber extraction method should involve extra research and mathematical modeling. Mathematical modeling was performed to develop adequate formula concerning flotation of different amber fractions in air-sand mixture with different density levels and use it as a basis for mathematical dependences.

In the context of hydromechanical extraction, amber dispacement within sand formation is characterized by the resistance of a dry friction type. Particles of amber, immersed into the environment, performs horizontal translatory vibration with $\omega$ frequency and trajectory radius $r$.

\section{Mathematical representation of hydromechanical amber extraction}

Consider a model of action of friction forces effecting amber particle (Fig. 1). Relying upon research by I.I. Blekhman for water-air mixture, specify resistance force in terms of any relative horizontal displacement of the particle through $F_{h}$; if the displacement is vertical, then it is specified through $F_{v}$. Specify a particle mass through $m_{1}$ taking into consideration associated environmental mass and the environmental mass in terms of volume being equal to the particle volume through $m_{0}$; specify average particle density-environment ratio through $\Delta=\rho / \rho_{0}$. To do that, assume that $x, y$, and $z$ are components of rectangular coordinate system XYZ of relative particle velocity within the environment.

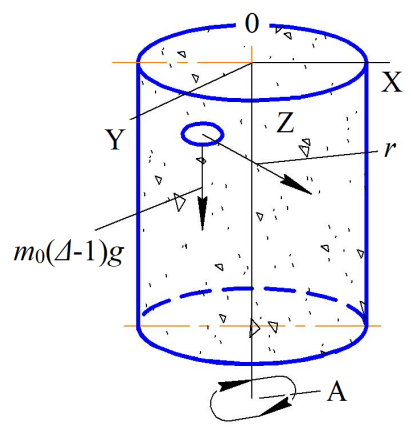

Fig. 1. Forces acting on the particle within the rock mass with the resistance of a dry friction type. 
Differential equations of the particle motion as for the amber-bearing environment can be expressed as follows:

$$
\begin{gathered}
m_{1} \ddot{x}=m_{0}(\Delta-1) r \omega^{2} \cos \omega t-F_{h} \frac{\dot{x}}{\sqrt{\dot{x}^{2}+\dot{y}^{2}+\dot{z}^{2}}} ; \\
m_{1} \ddot{y}=m_{0}(\Delta-1) r \omega^{2} \cos \omega t-F_{h} \frac{\dot{y}}{\sqrt{\dot{x}^{2}+\dot{y}^{2}+\dot{z}^{2}}} ; \\
m_{1} \ddot{z}=m_{0}(\Delta-1) g-F_{v} \frac{\dot{z}}{\sqrt{\dot{x}^{2}+\dot{y}^{2}+\dot{z}^{2}}} ; \\
\sqrt{\dot{x}^{2}+\dot{y}^{2}+\dot{z}^{2}} \neq 0 \\
\sqrt{\dot{x}^{2}+\dot{y}^{2}+\dot{z}^{2}} \neq 0 .
\end{gathered}
$$

Consider a ratio:

$$
\frac{F_{v}}{m_{0} g}>|\Delta-1|>\left[\left(\frac{m_{0} r \omega^{2}}{F_{h}}\right)^{2}+\left(\frac{m_{0} g}{F_{v}}\right)^{2}\right]^{-1 / 2},
$$

reflecting following condition: on the one hand, the particle mass within the environment is less than its resistance force of its vertical motion; on the other hand, inertia in terms of relative motion is sufficient to overcome resistance force of dry friction type. At the same time, dependences $(1-4)$ suppose accurate solution:

$$
\dot{x}=R \omega \cos (\omega t+\beta), \dot{y}=R \omega \sin (\omega t+\beta), \dot{z}=\dot{Z}_{0},
$$

corresponding to the particle motion as for the environment in terms of a spiral path. In this context, following expressions are derived for radius of a spiral line $R$ and vertical motion of $\dot{Z}_{0}$ particle velocity:

$$
\begin{gathered}
R=r \sqrt{\left[\frac{m_{0}}{m_{1}}(\Delta-1)\right]^{2}-\left[\frac{F_{h}}{m_{1} r \omega^{2}}\right]^{2}\left(1-\delta^{2}\right)} ; \\
\delta=m_{0}(\Delta-1) g / F_{v} ; \\
\dot{Z}_{0}=\frac{\delta}{\sqrt{1-\delta^{2}}} R \omega .
\end{gathered}
$$

Henceforth, expression for phase displacement $\beta$ is insignificant and the determined motion is stable [17-19]. It follows from dependence (9) that the amber particles which density is more than the environment density $(\Delta>1)$ immerse; the particles which density is less than the environment density $(\Delta<1)$ float. In this context, an effect when dry friction is transforming into viscous friction takes place.

If we compare dependence (9) with the known expression for the velocity of free fall of a spherical particle in viscous liquid in terms of small numbers of Reynolds, we have: 


$$
\dot{Z}^{*}=\frac{m_{0}(\Delta-1) g}{3 \pi \mu^{*} d},
$$

where $d$ is the amber particle diameter, and $\mu^{*}$ is viscosity coefficient of a liquid.

Determine true viscosity of amber-bearing environment:

$$
\mu^{*}=\frac{F_{v} \sqrt{1-\delta^{2}}}{3 \pi d R \omega}=\frac{F_{v}}{3 \pi d r \omega}\left\{\left[\frac{m_{0}(\Delta-1)}{m_{1} \sqrt{1-\delta^{2}}}\right]^{2}-\left[\frac{F_{h}}{m_{1} r \omega^{2}}\right]^{2}\right\}^{-1 / 2},
$$

The considered system is typical in the fact that the established motions are divided naturally: vertical particle motion is rapid and horizontal motion is slow. Moreover, in terms of $\dot{Z}=$ const, dependences of rapid motions $(1-4)$ accept accurate periodical solution of the type:

$$
x^{*}=R_{1} \omega \cos \left(\omega t+\beta_{1}\right), \dot{y}^{*}=R_{1} \omega \sin \left(\omega t+\beta_{1}\right) .
$$

Substituting the solution for dependence (3), we obtain a dependence of a slow vertical motion of the particle (fundamental equation of vibration mechanics):

$$
\begin{aligned}
& m_{1} \ddot{Z}=m_{0}(\Delta-1) g+V(\dot{Z}) ; \\
& V(\dot{Z})=-F_{v} \dot{Z}\left(R_{1}^{2} \omega^{2}+\dot{Z}^{2}\right)^{-1 / 2},
\end{aligned}
$$

is vibration force which obtaining does not involve averaging. As we can see, the force is of nonlinear viscous resistance nature $[V(0)=0]$. In the context of full inertial approximation when it is possible to consider that $F_{h} \ll m_{0}(\Delta-1) r \omega^{2}$, we obtain $\beta \approx-\pi / 2$ and $R_{1}=r(\Delta-1) m_{0} / m_{1}$ from the dependences $(1-4)$; according to formula (14) we obtain vibration force acting on the amber particle and making it move:

$$
V(\dot{Z}) \approx-F_{v} \dot{Z}\left\{\left[\frac{m_{0}}{m_{1}}(\Delta-1) r \omega\right]^{2}+\dot{Z}^{2}\right\}^{-1 / 2} .
$$

To determine a period for different amber particles surfacing in terms of different operation modes while comparing data of natural experiment and theoretical studies, simulate distribution of amber concentration at the surface of the deposit. To do that it is required to apply nonlinear differential equations within partial derivatives describing onedimensional slow process of changes in volumetric concentrations $c_{1}, \ldots, c_{n}$ of loose mixture components, i.e. corresponding equations of vibration mechanics:

$$
\frac{\partial c_{i}}{\partial t}=\frac{\partial}{\partial t}\left[\frac{\partial c_{i}}{\partial z} \sum_{j=1}^{n} a_{i j} c_{j}\right]-\frac{\partial}{\partial z}\left[c_{i}\left(\sum_{j=1}^{n} b_{i j} c_{j}+\sum_{j=1}^{n} a_{i j} \frac{\partial c_{j}}{\partial z}\right)\right](i=1, \ldots, n),
$$

where $Z$ is spatial coordinate; $a_{i j}$ and $b_{i j}$ are functions of $z$ being determined either basing upon studies of "rapid" process or experimentally. They depend upon properties and characteristics of particles as well as upon vibration parameters in the neighborhood of the point [20 - 22]. 
Experimental methods in laboratory conditions are the most efficient, such as mining and laboratory investigations and modelling on equivalent materials [23, 24]. If the experimental research in real conditions is impossible, in connection with evaluation of the initial investigated task state or presence of constraints, mathematical modelling and computer experiment are interrelated $[25,26]$. The process was modeled within software environment Matlab with the use of M-function "pdepe" meant to solve one-dimensional boundary problems for the systems of parabolic and elliptic differential equations within first-order partial differential derivatives in terms of one spatial variable and time.

\section{Results and discussion}

While using computer modeling according to the input data $\left(\left.c\right|_{t=0}=100 \mathrm{~g} / \mathrm{m}^{3},\left.c\right|_{x=0}=0\right.$, $\left.\frac{\partial C}{\partial x}\right|_{x=L}=0, D=0.0001 \mathrm{~m}^{2} / \mathrm{s}, L=1 \mathrm{~m}$ ) following results were obtained for different amber fractions (Table 1).

Table 1. Classification of the extracted amber.

\begin{tabular}{|c|c|c|}
\hline No. & $\begin{array}{c}\text { Amber sizing according } \\
\text { to weight, } g\end{array}$ & $\begin{array}{c}\text { Distribution of the extracted } \\
\text { amber, } \%\end{array}$ \\
\hline 1 & 5 & 5 \\
\hline 2 & 3 & 22 \\
\hline 3 & 1 & 12 \\
\hline 4 & 5 & 15 \\
\hline 5 & 2 & 30 \\
\hline 6 & Others & 16 \\
\hline & Total & 100 \\
\hline
\end{tabular}

Table 2 demonstrates the results of the research concerning distribution of amber concentration at the deposit surface for different fractions as well as in the form of dependence graphs resulting from computer modeling in terms of different operation modes of the facilities (i.e. combination of vibration, water, and air - v-w-a; supply of water and air - w-a; and water supply without air and vibration - w).

Table 2. Calculation data concerning distribution of amber concentration at the deposit surface, if mining depth is $1 \mathrm{~m}$.

\begin{tabular}{|c|c|c|c|c|c|c|c|c|c|c|c|}
\hline \multicolumn{2}{|c|}{ No. } & \multicolumn{10}{|c|}{ Distribution of amber concentration at the deposit surface while mining, $\mathrm{g} / \mathrm{m}^{3}$} \\
\hline \multirow{3}{*}{$\begin{array}{c}\text { Fraction } \\
2 \mathrm{~mm}\end{array}$} & $\mathrm{v}-\mathrm{w}-\mathrm{a}$ & 0.826 & 22.86 & 29.19 & 30.54 & 30.84 & 30.9 & 30.91 & 30.92 & 30.92 & 30.92 \\
\hline & $\mathrm{w}-\mathrm{a}$ & 0.09 & 16.51 & 25.37 & 28.71 & 30.03 & 30.57 & 30.78 & 30.86 & 30.9 & 30.91 \\
\hline & $\mathrm{W}$ & 0.004 & 10.46 & 20.06 & 24.9 & 27.54 & 29.02 & 29.85 & 30.31 & 30.58 & 30.73 \\
\hline \multirow{3}{*}{$\begin{array}{c}\text { Fraction } \\
5 \mathrm{~mm}\end{array}$} & v-w-a & 0.533 & 12.73 & 15.07 & 15.39 & 15.43 & 15.44 & 15.44 & 15.44 & 15.44 & 15.44 \\
\hline & $\mathrm{w}-\mathrm{a}$ & 0.059 & 9.667 & 13.77 & 14.94 & 15.29 & 15.39 & 15.42 & 15.43 & 15.44 & 15.44 \\
\hline & $\mathrm{W}$ & 0.002 & 6.36 & 11.44 & 13.59 & 14.57 & 15.03 & 15.24 & 15.35 & 15.39 & 15.42 \\
\hline \multirow{3}{*}{$\begin{array}{c}\text { Fraction } \\
10 \mathrm{~mm}\end{array}$} & v-w-a & 0.476 & \begin{tabular}{|l|l|}
10.84 \\
\end{tabular} & 12.58 & 12.78 & 12.81 & 12.81 & 12.81 & 12.81 & 12.81 & 12.81 \\
\hline & $\mathrm{w}-\mathrm{a}$ & 0.053 & 8.361 & 11.65 & 12.49 & 12.72 & 12.78 & 12.8 & 12.81 & 12.81 & 12.81 \\
\hline & W & 0.053 & 8.361 & 11.65 & 12.49 & 12.72 & 12.78 & 12.8 & 12.81 & 12.81 & 12.81 \\
\hline \multirow{3}{*}{$\begin{array}{l}\text { Fraction } \\
30 \mathrm{~mm}\end{array}$} & v-w-a & 7.124 & 21.91 & 22.13 & 22.13 & 22.13 & 22.13 & 22.13 & 22.13 & 22.13 & 22.13 \\
\hline & $\mathrm{w}-\mathrm{a}$ & 0.217 & 14.83 & 20.19 & 21.6 & 21.98 & 22.09 & 22.12 & 22.13 & 22.13 & 22.13 \\
\hline & $\mathrm{W}$ & 0.001 & 7.124 & 14.25 & 17.8 & 19.72 & 20.78 & 21.37 & 21.7 & 21.89 & 21.99 \\
\hline \multirow{3}{*}{$\begin{array}{l}\text { Fraction } \\
50 \mathrm{~mm}\end{array}$} & v-w-a & 0.803 & 4.776 & 4.849 & 4.85 & 4.85 & 4.85 & 4.85 & 4.85 & 4.85 & 4.85 \\
\hline & $\mathrm{w}-\mathrm{a}$ & 0.03 & 3.809 & 4.707 & 4.829 & 4.847 & 4.849 & 4.85 & 4.85 & 4.85 & 4.85 \\
\hline & $\mathrm{w}$ & $4 \mathrm{E}-04$ & 2.424 & 4.093 & 4.598 & 4.764 & 4.82 & 4.84 & 4.846 & 4.848 & 4.849 \\
\hline
\end{tabular}


Fig. 2 and 3 have been developed relying upon the data represented in Table 2.

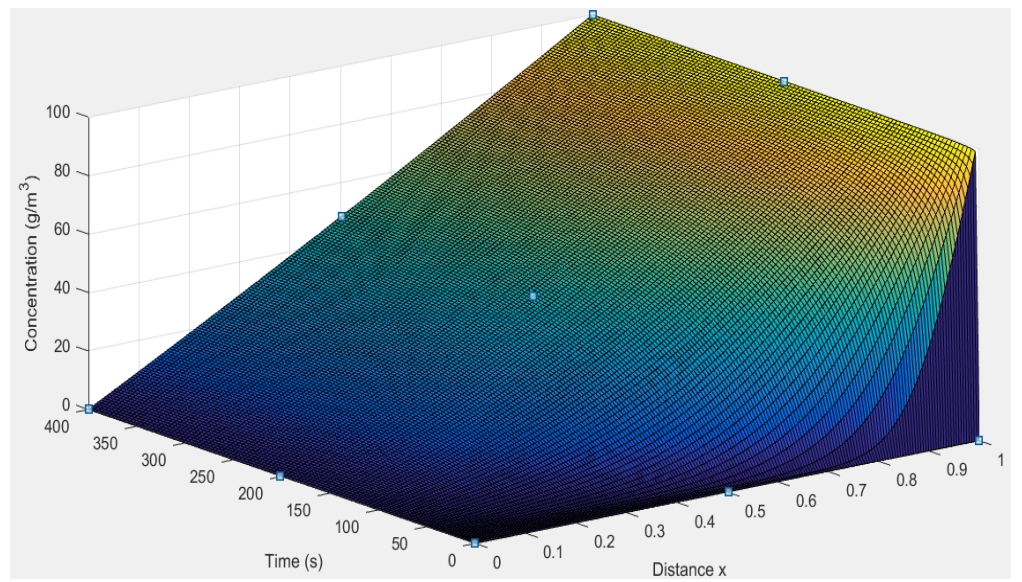

Fig. 2. Spatial distribution of amber concentration within amber-bearing deposit.
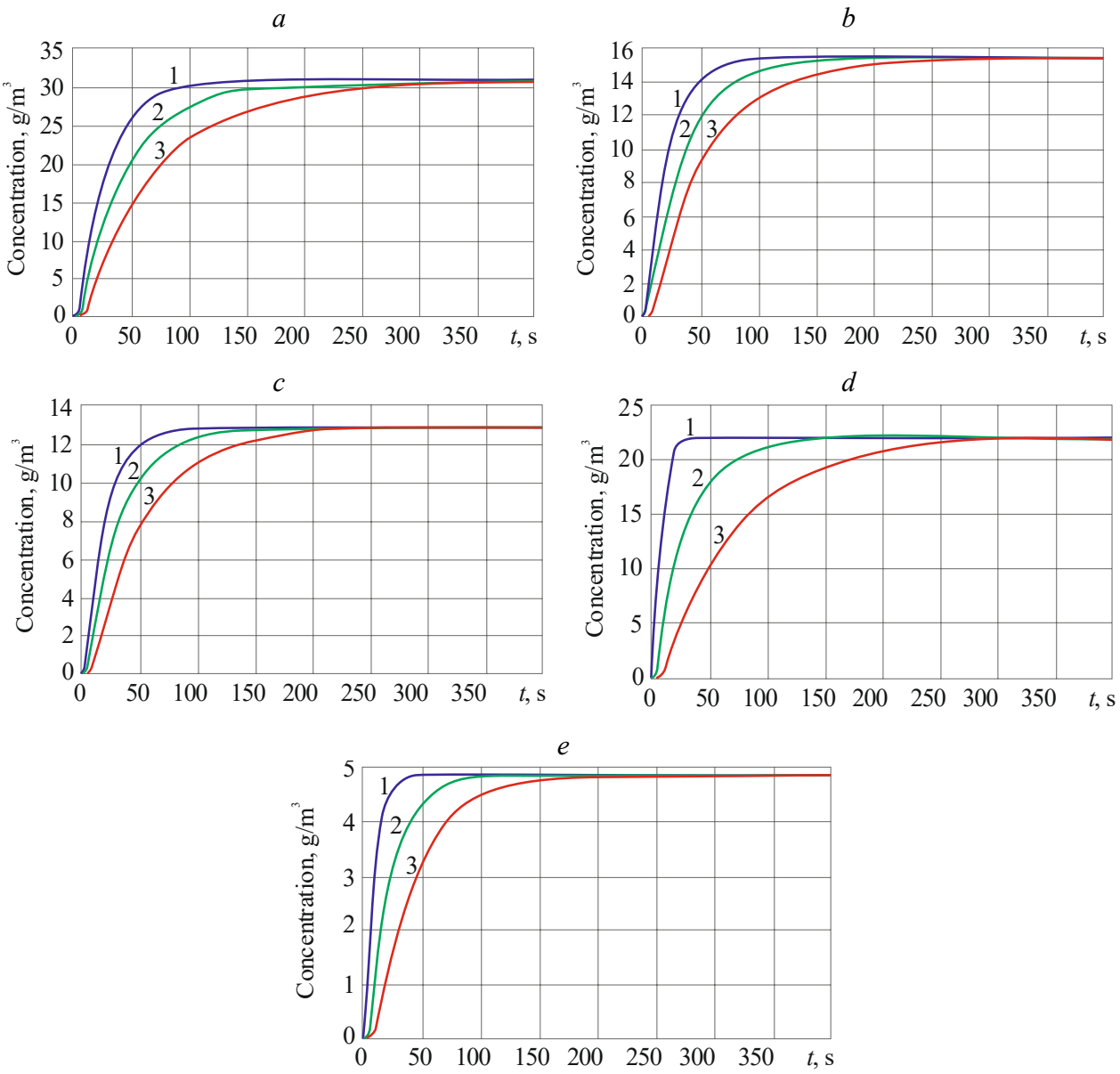

Fig. 3. Distribution of amber concentration at the deposit surface while mining: $a-2 \mathrm{~mm} ; b-5 \mathrm{~mm}$; $\mathrm{c}-10 \mathrm{~mm} ; \mathrm{d}-30 \mathrm{~mm}$; $-50 \mathrm{~mm} ; 1-\mathrm{v}-\mathrm{w}-\mathrm{a} ; 2-\mathrm{w}-\mathrm{a}$; and $3-\mathrm{w}$ ( $2 \mathrm{~mm}$ fraction). 
Therefore, it is obvious that improvement of technology and equipment is possible at the expense of amber extraction intensification when sand deposit is saturated with water, air, and vibration in the form of mechanical effect. Amber floating within sand deposit is characterized by the environmental resistance and effect of prevailing factors providing the amber surfacing. The modeling makes it possible to develop dependence as for distribution of amber concentration over the deposit surface when the time of different amber fractions flotation is determined in terms of different operation modes. Integrated action of vibration, water and air supply intensify the process of amber floating while determining surfacing velocity. Hence, the velocity is a technological parameter used to determine productivity of equipment. Complete floating of the finest amber fractions (i.e. $2 \mathrm{~mm}$ ) from $1 \mathrm{~m}$ depth to a surface takes 50 seconds. Floating process duration helps determine productivity of equipment and simulate processes of amber flotation from different depths. The obtained adequate mathematical model to solve one-dimensional boundary problems describes accurately behaviour of different amber particles within amber-bearing deposits when vibration acts, and water and air are supplied.

\section{Conclusions}

Mathematical model to solve one-dimensional boundary problems for the systems of parabolic and elliptic differential equations within first-order partial derivatives on one spatial variable and time has been developed as a result of amber surfacing process. The model describes accurately the behaviour of different amber fractions within amber-bearing deposit in terms of vibration, and water and air supply. The research has determined that larger amber fractions surface faster.

This work was supported by the Ministry of Education and Science of Ukraine (State registration No. 0102U001910).

\section{References}

1. Mykhailov, V., \& Kurylo, M. (2011). Estimation of flux reserve and resource base of Ukraine. International Multidisciplinary Scientific GeoConference Surveying Geology and Mining Ecology Management, SGEM, 135-140. https://doi.org/10.5593/sgem2015/b11/s1.018

2. Bondarenko, V., Cherniak, V., Cawood, F., \& Chervatiuk, V. (2017). Technological safety of sustainable development of coal enterprises. Mining of Mineral Deposits, 11(2), 1-11. https://doi.org/10.15407/mining11.02.001

3. Petlovanyi, M.V., Lozynskyi, V.H., Saik, P.B., \& Sai, K.S. (2018). Modern experience of lowcoal seams underground mining in Ukraine. International Journal of Mining Science and Technology. Article in press. https://doi.org/10.1016/j.ijmst.2018.05.014

4. Khomenko, O.Ye., Sudakov, A.K., Malanchuk, Z.R., \& Malanchuk, Ye.Z. (2017). Principles of rock pressure energy usage during underground mining of deposits. Naukovyi Visnyk Natsionalnoho Hirnychoho Universytetu, (2), 34-43.

5. Bondarenko, V., Lozynskyi, V., Sai, K., \& Anikushyna, K. (2015). An overview and prospectives of practical application of the biomass gasification technology in Ukraine. New Developments in Mining Engineering 2015: Theoretical and Practical Solutions of Mineral Resources Mining, 27-32. https://doi.org/10.1201/b19901-6

6. Kovalevskii, S.B., \& Lehkyi, V.V. (2017). The integral estimate of the anthropogenic transformation of forest landscapes of Dubrovytsia region as a result of unsecured extraction of amber. Scientific Bulletin of UNFU, 27(9), 52-55.

7. Masley, V.M., Mozgovoy, D.K., Bilousov, K.G., Horoshilov, V.S., Bushanska, O.S., \& Galich, N.G. (2016). Methods of the impact evaluation of amber mining by multispectral satellite images. 
Kosmicna Nauka i Tehnologia, 22(6), 26-36.

8. Alekseev, V.I. (2013). The beetles (Insecta: Coleoptera) of Baltic amber: the checklist of described species and preliminary analysis of biodiversity. Zoology and Ecology, 23(1), 5-12. https://doi.org/10.1080/21658005.2013.769717

9. Wang, S., Shi, C., Zhang, Y.-j., Hu, G.-x., \& Gao, L.-z. (2016). Trading away ancient amber's secrets. Science, 351 (6276), 926. https://doi.org/10.1126/science.351.6276.926-a

10. Yablokov, A., Levchenko, V., \& Kerzhentsev, A. (2017). The Biosphere as a Living System. On the Harmonization of Human and Biosphere. Philosophy and Cosmology, (18), 52-83.

11. Bulat, A.F. (2016). Promyslovi tehnolohii vydobytku burshtynu. Dnipro: Instytut heotehnichnoi mehaniky.

12. Krynytska, M.V., \& Korniienko, V.Ya. (2018). Obgruntuvannia heolohichnykh umov ta tekhnolohichni osnovy vydobutku poliskoho burshtynu. In Poturaivski Chytannia, 32-39.

13. Macuj, V.M. (2013). Basic Amber Problems at the Present Stage. Sbornik Nauchnyh Trudov, Posvyashchennyy 150-letiyu so Dnya Rozhdeniya Akademika P.A. Tutkovskogo, 339-346.

14. Haletskyi, L.S., \& Remezova, O.O. (2012). Outlooks of Prospecting for New Amber Deposits in Ukraine. Identykatsiia Vykopnykh Smol. Zbornik Materialiv Naukovoho Seminaru, 63.

15. Macuj, V.M. (2013). Marine Stage of Fossilization of Resin Extraction from Conifers in Transforming Them to Amber-Succinite. Geologiya i poleznye iskopaemyeh. (2), 101-108.

16. Belichenko, O., \& Ladzhun, J. (2016). Complex gemological research of new types of treated amber. Visnyk of Taras Shevchenko National University of Kyiv. Geology, 4(75), 30-34. https://doi.org/10.17721/1728-2713.75.04

17. Malanchuk, Z., Korniyenko, V., Malanchuk, Y., \& Khrystyuk, A. (2016). Results of experimental studies of amber extraction by hydromechanical method in Ukraine. Eastern-European Journal of Enterprise Technologies, 3(10(81)), 24. https://doi.org/10.15587/1729-4061.2016.72404

18. Nadutyy, V.P., \& Korniyenko V.Ya. (2016). Research of process of extraction amber from amber containing deposits vibro classifier. Vibratsiia v Tekhnitsi ta Tekhnolohiiakh, 3(83), 117-121.

19. Nadutyi, V.P. (2016). Doslidzhennia vplyvu pokaznykiv vibratsii na vydobutok burshtynu z pishchanykh rodovyshch. Heotekhnichna Mekhanika, (126), 27-35.

20. Malanchuk, Z., Malanchuk, Ye., \& Khrystiuk, A. (2016). Mathematical modeling of hydraulic mining from placer deposits of minerals. Mining of Mineral Deposits, 10(2), 18-24. https://doi.org/10.15407/mining10.02.018

21. Malanchuk, Z., Korniienko, V., \& Malanchuk, Ye. (2017). Results of research into amber mining by hydromechanical method. Mining of Mineral Deposits, 11(1), 93-99. https://doi.org/10.15407/mining11.01.093

22. Malanchuk, Z., Korniienko, V., Malanchuk, Ye., Soroka, V., \& Vasylchuk, O. (2018). Modeling the formation of high metal concentration zones in man-made deposits. Mining of Mineral Deposits, 12(2), 76-84. https://doi.org/10.15407/mining12.02.076

23. Lozynskyi, V.G., Dychkovskyi, R.O., Falshtynskyi, V.S., Saik, P.B., \& Malanchuk, Ye.Z. (2016). Experimental study of the influence of crossing the disjunctive geological faults on thermal regime of underground gasifier. Naukovyi Visnyk Natsionalnoho Hirnychoho Universytetu, (5), 21-29.

24. Lozynskyi, V., Saik, P., Petlovanyi, M., Sai, K., \& Malanchyk, Ye. (2018). Analytical Research of the Stress-Deformed State in the Rock Massif Around Faulting. International Journal of Engineering Research in Africa, (35), 77-88. https://doi.org/10.4028/www.scientific.net/JERA.35.77

25. Cabana, E.C. (2017). Formation of thermal fields by the energy-chemical complex of coal gasification. Naukovyi Visnyk Natsionalnoho Hirnychoho Universytetu, (5), 36-42.

26. Dychkovskyi, R.O., Lozynskyi, V.H., Saik, P.B., Petlovanyi, M.V., Malanchuk, Ye.Z., \& Malanchuk, Z.R. (2018). Modeling of the disjunctive geological fault influence on the exploitation wells stability during underground coal gasification. Archives of Civil and Mechanical Engineering, 18(4). https://doi.org/10.1016/j.acme.2018.01.012 